\title{
PEMBANGUNAN MODUL PENAWARAN PADA SIAPSIAPNIKAH.COM DENGAN METODE EXTREME PROGRAMMING DAN KONSEP CROWDSOURCING
}

\author{
${ }^{1}$ Ganang Afif Rijazim, ${ }^{2}$ Yuli Adam Prasetyo, ${ }^{3}$ Taufik Nur Adi \\ 1,2,3 Program Studi Sistem Informasi, Fakultas Rekayasa Industri, Telkom University \\ ${ }^{1}$ ganafif@gmail.com, ${ }^{2}$ adam@telkomuniversity.ac.id, ${ }^{3}$ taufik.nur.adi@gmail.com
}

\begin{abstract}
Abstrak-Jumlah pernikahan di Indonesia selalu meningkat setiap tahunnya. Sekitar 2.250 .000 pernikahan terjadi pada tahun 2012. Dalam mempersiapkan pesta pernikahan membutuhkan tenaga, energi, dan waktu yang banyak. Untuk membantu pengantin dan keluarga dalam mempersiapkan pernikahan, kebanyakan dari mereka menggunakan layanan wedding organizer (WO). Saat ini, sebelum memutuskan WO mana yang akan digunakan kebanyakan masyarakat datang langsung ke kantor WO atau ke pameran pernikahan. Berdasarkan hasil survei, kebanyakan WO belum memiliki media digital seperti website yang digunakan untuk mempromosikan jasa dan produknya. Akan tetapi, kebanyakan pelanggan ingin menemukan jasa atau produk terbaik dari WO dengan melakukan pencarian melalui internet karena saat ini internet sangat mudah didapatkan. Penelitian ini mengembangkan aplikasi website untuk WO dan pelanggan dengan sistem penawaran dan konsep crowdsourcing berdasarkan permasalahan dan peluang. Dengan aplikasi website ini, pelanggan dan WO memiliki satu tempat khusus untuk menemukan WO atau paket terbaik dan untuk mempromosikan jasa serta produk WO. Selain dengan konsep crowdsourcing, webite ini juga menerapkan sistem penawaran untuk mendukung proses bisnisnya. Sistem penawaran pada website ini memiliki dua fungsi utama, yaitu pelanggan mencari dan memesan paket yang paling cocok, serta memberikan kesempatan kepada member untuk menentukan paket yang dia inginkan. Website ini masih perlu pembenahan terutama dalam hal desain dan keamanan website. Hal tersebut didasari dengan hasil testing yang dilakukan dalam penelitian ini.
\end{abstract}

Kata kunci: wedding organizer, aplikasi website, penawaran, crowdsourcing, extreme programming.

\section{PENDAhUluan}

Di Indonesia, banyak perusahaan jasa Wedding Organizer (WO). Argumen ini berdasarkan hasl survei pada "weddingku.com". Dari hasil survei yang dilakukan oleh peneliti pada "weddingku.com", ada 509 WO yang terdaftar pada "weddingku.com" dan berlokasi di beberapa wilayah di Indonesia. Hanya 79 WO dari 509 WO yang memiliki website. Sisanya tidak memiliki website. Pada kenyataannya, perkembangan teknologi menyediakan banyak fasilitas untuk WO yang mebantu mengembangkan bisnis yang dijalani. Salah satu contoh dari manfaat perkembangan teknologi bagi WO adalah, membantu memasarkan produk dan jasa WO melalui internet.

Pada sisi pelanggan, kebanyakan dari pelanggan menggunakan fasilitas website untuk mencari informasi tentang layanan yang disediakan oleh WO daripada menggunakan media lain. Dibuktikan dari survei kepada 108 responden (pelanggan) bahwa website adalah salah satu media yang menarik untuk mencari informasi WO. Pelanggan ingin mendapatkan cara yang sederhana untuk mencari WO yang paling bagus dan mencari paket yang paling sesuai dengan harga dan kualitas yang ditentukan oleh pelanggan. Namun, hanya beberapa pelanggan dan WO yang mengetahui konsep crowdsourcing dan menggunakannya untuk mendukung aktivitas yang mereka lakukan. Website dengan konsep crowdsourcing sangat membantu bagi mereka. Mereka dapat melakukan semua aktivitas bisnis pernikahan pada satu tempat.

Selain website crowdsourcing, untuk memenuhi kebutuhan pelanggan dan WO disediakanlah sistem penawaran. Sistem ini membantu pelanggan untuk menemukan paket pernikahan yang terbaik dan menemukan layanan yang ditawarkan oleh pihak WO. Kombinasi antara konsep crowdsourcing dengan sistem penawaran pada satu aplikasi website adalah konsep yang dikembangkan dalam penelitian ini. Berdasarkan survei pada penelitian ini yang dilakukan pada 56 pelanggan dan $14 \mathrm{WO}, 87 \%$ pelanggan ingin menggunakan website dengan konsep ini dan $100 \%$ WO ingin bergabung pada website yang akan di kembangkan di penelitian ini. Dengan alasan tersebut dan melihat potensi pengimplementasian aplikasi website ini di Indonesia, maka website ini dibuat untuk memberikan fasilitas kepada pelanggan dan WO dalam bisnis pernikahan.

\section{Metodologi Penelitian}

\section{A. Wedding Organizer}

Untuk mempersiapkan pesta pernikahan biasanya masyarakat Indonesia menggunakan jasa wedding organizer agar lebih efektif dan efisien dalam segala keperluannya. Definisi dari wedding organizer itu sendiri adalah bisnis yang menyediakan layanan tentang manajemen semua kegiatan pernikahan dan mempersiapkan semua kebutuhan pernikahan 
[1]. Saat ini jasa wedding organizer di Indonesia memiliki peluang yang besar untuk mengembangkan bisnis ini. Karena dengan layanan wedding organizer pelanggan dari WO tersebut yang membutuhkan fleksibilitas, kecepatan dan kemudahan dalam mempersiapkan pernikahan sangat terbantu persiapan pernikahannya.

\section{B. Crowdsourcing}

Crowdsourcing diartikan secara kata per kata mempunyai terjemahan bebas, yakni Crowd: kerumunan orang, Sourcing (kata kerja dari Source): sumber daya. Apabila digabungkan (masih dalam terjemahan bebas) berarti sebagai sesuatu sistem atau konsep yang sumber daya berbasis kerumunan. Selain itu, definisi sederhana crowdsourcing menurut JeffPHowe adalah suatu aktivitas atau tindakan yang dilakukan oleh suatu perusahaan atau institusi yang mengambil salah satu fungsi pekerjaan/tugas yang seharusnya dilakukan oleh karyawannya disebarluaskan secara terbuka dan bebas untuk orang banyak/kerumunan yang terkoneksi dengan jaringan komputer, dalam hal ini internet [2].

\section{Sistem Penawaran}

Teori penawaran dan permintaan dalam ilmu ekonomi, adalah penggambarkan atas hubungan-hubungan di pasar, antara para calon pembeli dan penjual dari suatu barang. Model penawaran dan permintaan digunakan untuk menentukan harga dan kuantitas yang terjual di pasar [3]. Pada penelitian ini, teori penawaran akan diterapkan dalam sebuah website namun tidak menghilangkan makna dari sistem penawaran itu sendiri. Objek yang akan melakukan sistem penawaran dalam website ini adalah penyedia layanan wedding organizer dan calon pengguna layanan wedding organizer.

\section{Extreme Programming}

Dalam pengertiannya "Extreme programming (XP for short) is a pure agile method. XP is based on a number of best practices that have been known for a long time. XP take these practices to extreme level'[4]. Metode ini tepat dilakukan pada pengembangan proyek dan aplikasi yang ingin mendapatkan hasil yang inovatif dan sempurna dengan cara yang tidak kompleks.

\section{E. Model Konseptual}

Model konseptual adalah sebuah rancangan yang terstruktur yang didalamnya terdapat konsep-konsep yang saling berkaitan dan terorganisasi untuk melihat dan mengetahui hubungan dan pengaruh logis antarkonsep. Selain itu, model konseptual juga digunakan untuk mengatur pola pikir, mengamati apa yang dilihat dan memperjelas arah penelitian sehingga dapat digunakan untuk menentukan pertanyaan-pertanyaan dan digunakan untuk mencari solusi dari masalah [5]. Atau, dalam pengertian lain adalah konsep pemikiran yang membantu peneliti untuk merumuskan pemecahan masalah dan membantu dalam merumuskan solusi permasalahan yang ada [6]. Dalam penelitian ini, model konseptual yang digunakan dapat dilihat pada Gambar 1 .
Konsep dalam pembuatan aplikasi website ini didasari oleh latar belakang dari penelitian ini. Latar belakang pada penelitian ini termasuk rumusan masalah, batasan masalah, landasan teori, analisis kebutuhan dan kuesioner serta hasil wawancara. Semua bagian dari latar belakang tersebut menjadi dasar pengembangan aplikasi website siapsiapnikah.com pada modul penawaran

Pada modul penawaran siapsiapnikah.com, terdapat dua tipe sistem online, yaitu Online Transaction Processing (OLTP) dan Online Analytical Processing (OLAP). Sistem OLTP pada modul penawaran menjelaskan layanan-layanan yang dibuat dan akan digunakan oleh user dari aplikasi website ini, sedangkan sistem OLAP menyediakan laporan dan hasil dari analisis pada layanan-layanan yang tersedia pada modul panawaran siapsiapnikah.com.

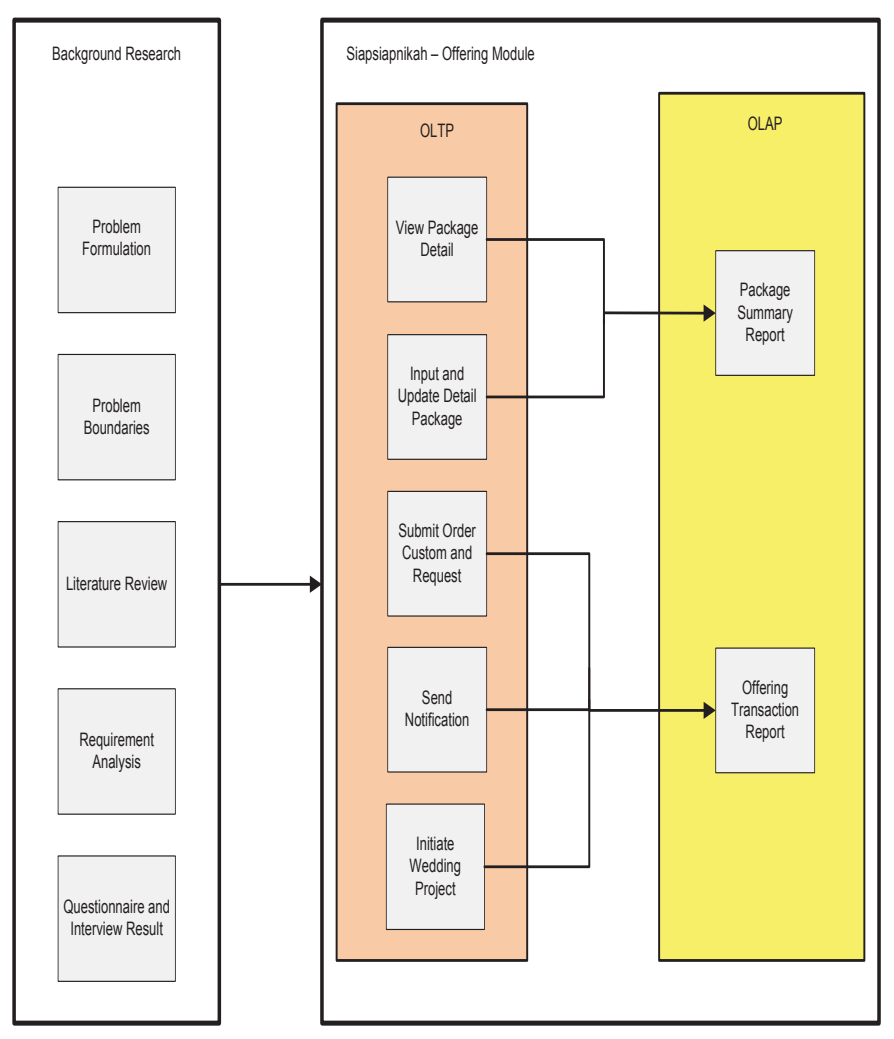

Gambar 1 Model Konseptual

\section{HASIL DAN PEMBAHASAN}

Aplikasi website yang dikembangkan pada penelitian ini adalah salah satu contoh website dengan konsep crowdsourcing untuk bisnis WO dengan sistem penawaran sebagai aktivitas utamanya. Website ini memiliki keunggulan daripada website sejenis yang ada. Keunggulan tersebut dapat kita lihat pada Tabel I. Semua aktivitas khususnya aktivitas penawaran terjadi pada website ini. Website ini membantu pelanggan untuk menemukan dan menawarkan paket yang paling sesuai dengan harga dan kualitas yang diinginkan. WO juga dapat mempromosikan dan menawarkan layanan dan paket yang mereka miliki pada satu tempat. Lebih sari satu pelangan dan 
WO dapat bergabung pada website ini. Layanan yang disediakan oleh website ini dibagi menjadi dua sudut pandang. Yaitu dari sudut pandang pelanggan dan sudut pandang WO.

TABEL I

PERBANDINGAN DENGAN WEBSITE LAIN

\begin{tabular}{|c|c|c|c|}
\hline Fitur & siapsiapnikah.com & weddingku.com & bridestory.com \\
\hline PencariWO & $\sqrt{ }$ & $\sqrt{ }$ & $\sqrt{ }$ \\
\hline $\begin{array}{c}\text { Pencarian } \\
\text { paket } \\
\text { pernikahan }\end{array}$ & $\sqrt{ }$ & $\sqrt{ }$ & \\
\hline Pesan paket & $\sqrt{ }$ & - & - \\
\hline $\begin{array}{c}\text { Pesan } \\
\text { customize } \\
\text { package }\end{array}$ & $\sqrt{ }$ & - & - \\
\hline $\begin{array}{c}\text { Notifikasi } \\
\text { pemesanan } \\
\text { untuk WO } \\
\text { dan }\end{array}$ & $\sqrt{ }$ & - & - \\
pengantin) & $\sqrt{ }$ & - & \\
\hline $\begin{array}{c}\text { Managemen } \\
\text { pesan }\end{array}$ & $\sqrt{ }$ & \\
\hline
\end{tabular}

A. Fungsionalitas Aplikasi Modul Penawaran

Berikut ini merupakan semua fitur penawaran yang disediakan di website ini.

1. Fitur untuk Pelanggan

a. Menemukan paket yang paling sesuai (advanced search):

fitur ini memberikan fasilitas untuk pelanggan dalam proses pencarian paket yang paling sesuai yang sudah disediakan oleh WO. Dalam proses pencariannya, pelanggan dapat menyaring kategori-kategori apa yang dijadikan parameter pencarian.

b. Uraian paket:

sebelum memesan paket, pelangan dapat melihat uraian paket yang dipesan. Mulai dari harga paket, kapasitas paket, WO penyedia paket hingga semua uraian kategori paket.

c. Pesan paket:

setelah pelanggan menemukan paket yang paling sesuai, mereka dapat paket tersebut dari WO yang memiliki paket tersebut. Pelanggan juga dapat mencari paket lain lagi, karena pada fitur ini memungkinkan pelanggan untuk mmesan lebih dari satu paket pernikahan

d. Uraian pesanan:

setelah memesan paket, pelanggan dapat melihat uraian pesanan mereka dengan fitur ini. Karena mereka membuthkan informasi dan harus mengetahui info yang spesifik dari pesanannya.

e. Daftar pesanan paket pernikahan:

pada halaman manajemen akun member terdapat satu tab untuk menampilkan daftar pesanan paket yang telah dilakukan. Dengan fitur ini, pelanggan dapat mengatur pesanannya.

f. Menghapus pesanan paket:

jika mereka ingin membatalkan pesanan mereka. Aplikasi website ini menyediakan fitur hapus pesanan paket. Fitur pembatalan order sangat penting karena pelanggan suatu saat pasti ingin membatalkan pesanannya.

g. Mengajukan paket yang dibuat oleh pelanggan:

pada sistem penawaran, pelanggan memiliki kesempatan untuk mengajukan paket buatan mereka sendiri kepada WO yang mereka inginkan. Dengan fitur ini, pelanggan dapat mengajukan paket sesuai apa yang mereka inginkan dan sesuai dengan kondisi keuangan mereka.

h. Memesan paket yang dibuat pelanggan:

Proses pemesanan ini digunakan setelah proses pembuatan paket yang diajukan. Mereka harus mengisi formulir pengajuan paket setelah mereka menentukan WO mana yang dituju. Setelah itu, pelanggan menunggu konfirmasi dari WO yang bersangkutan. Jika paket yang diajukan disetujui, proses selanjutnya dilakukan antara WO dan pelanggan itu sendiri. Pelanggan dapat mengajukan paket mereka kepada lebih dari satu WO namun harus dalam pemesanan lain.

i. Daftar pesanan pengajuan paket:

Setelah mengajukan paket buatan sendiri ke WO, semua proses transaksi ditampilkan pada halaman daftar pesanan paket yang ada di manajemen akum member. Pelanggan dapat mengatur pesanan mereka di halaman tersebut.

j. Uraian pesanan pengajuan paket:

Pelanggan dapat juga melihat uraian dari pesanan pengajuan paket mereka dengan fitur ini. Uraian pesanan yang ditampilkan menyajikan informasi tentang informasi WO yang terpilih, uraian paket yang diajukan dan status pemesanan.

k. Menghapus pesanan pengajuan paket:

Untuk melengkapi proses, kemungkinan pembatala proses dapat dilakukan dengan fitur ini. Pelanggan dapat membatalkan pesanan mereka dengan fitur ini.

2. Fitur untuk Wedding Organizer

a. Manajemen pesanan paket:

semua pesanan paket dari pelanggan yang memesan paket dari WO ditampilkan pada fitur ini. WO akan memperoleh informasi pemesan dan dapat memanajemen pesanannya. Bentuk dari proses manajemen pesanan yang dilakukan WO adalah melihat delail pemesanan, menerima pesanan, menolak pesanan, dan menghapus pesanan.

b. Manajemen pesanan pengajuan paket:

sama dengan manajemen pemesanan paket, hanya saja fitur ini berguna untuk mengatur pesanan paket yang diajukan oleh pemesan. Aktivitas manajemen pesanannya juga sama dengan manajemen pesanan paket.

c. Melihat uraian pemesan:

dari status menunggu konfirmasi hingga pesanan diterima atau ditolak, WO dapat melihat uraian dari pemesan. Fitur ini digunakan untuk tahap selanjutnya khususnya ketika pesanan diterima. WO akan 
melakukan komunikasi langsung dengan pemesan sehingga data dari pemesan harus ditampilkan.

B. Arsitektur Aplikasi dan Teknologi

Untuk mengembangkan aplikasi website ini ada beberapa kebutuhan pendukungnya. Salah satu kebutuhan pendukungnya adalah web service. Web service digunakan untuk memanajemen semua komponen website seperti source code dan databasae sehingga website ini dapat diakses oleh penggunanya. Selain itu, konsep crowdsourcing menjadi panduan dalam pembuatan aplikasi website ini. Konsep crowdsourcing pada pengembangan aplikasi website ini secara umum digambarkan pada Gambar 2. Aplikasi website ini dikembangkan dengan menggunakan framework CodeIgniter dan menggunakan konsep MVC (model, view, controller). Kerangka kerja ini adalah kerangka kerja yang sering digunakan untuk mengembangkan sebuah website.

C. Hasil Aplikasi

Hasil penelitian dijelaskan dengan hasil tampilan User Interface-nya (UI). Terdapat tiga bagian UI, yaitu UI menemukan dan memesan paket, UI pemesana paket buatan pelanggan, dan UI dari wedding organizer. Gambar 3 dan Gambar 4 adalah registrasi member dan halaman sign in. Untuk mengakses sistem penawaran pada website ini, pelanggan harus menjadi member dan WO harus menjadi partner. Halaman registrasi untuk WO dapat dilihat pada Gambar 5.
Setelah bergabung menjadi partner, mereka harus masuk ke dalam website ini. Kemudian tampilan dari beranda website ini dapat dilihat pada Gambar 6. Pada halaman beranda terdapat informasi tentang layanan website (Gambar 7), WO partner, paket, tentang website ini, kontak website, dan iklan. Untuk menggunakan sistem penawaran, pelanggan harus masuk ke halaman sistem penawaran.

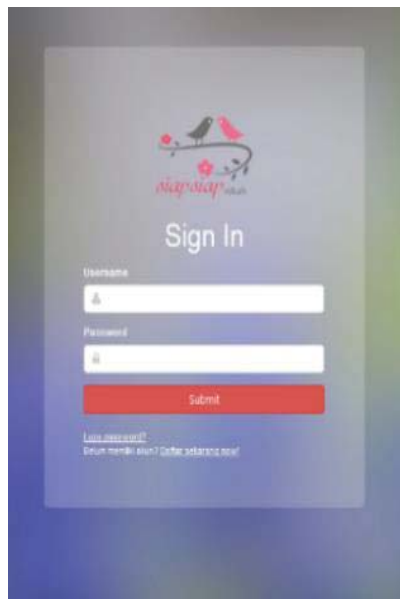

Gambar 3 Halaman Sign-in

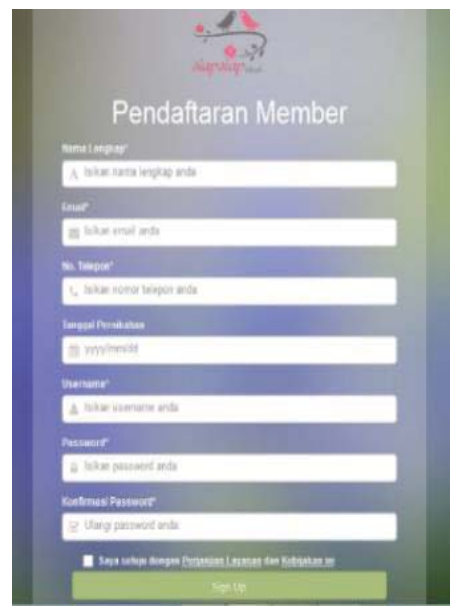

Gambar 4 Halaman Registrasi Member

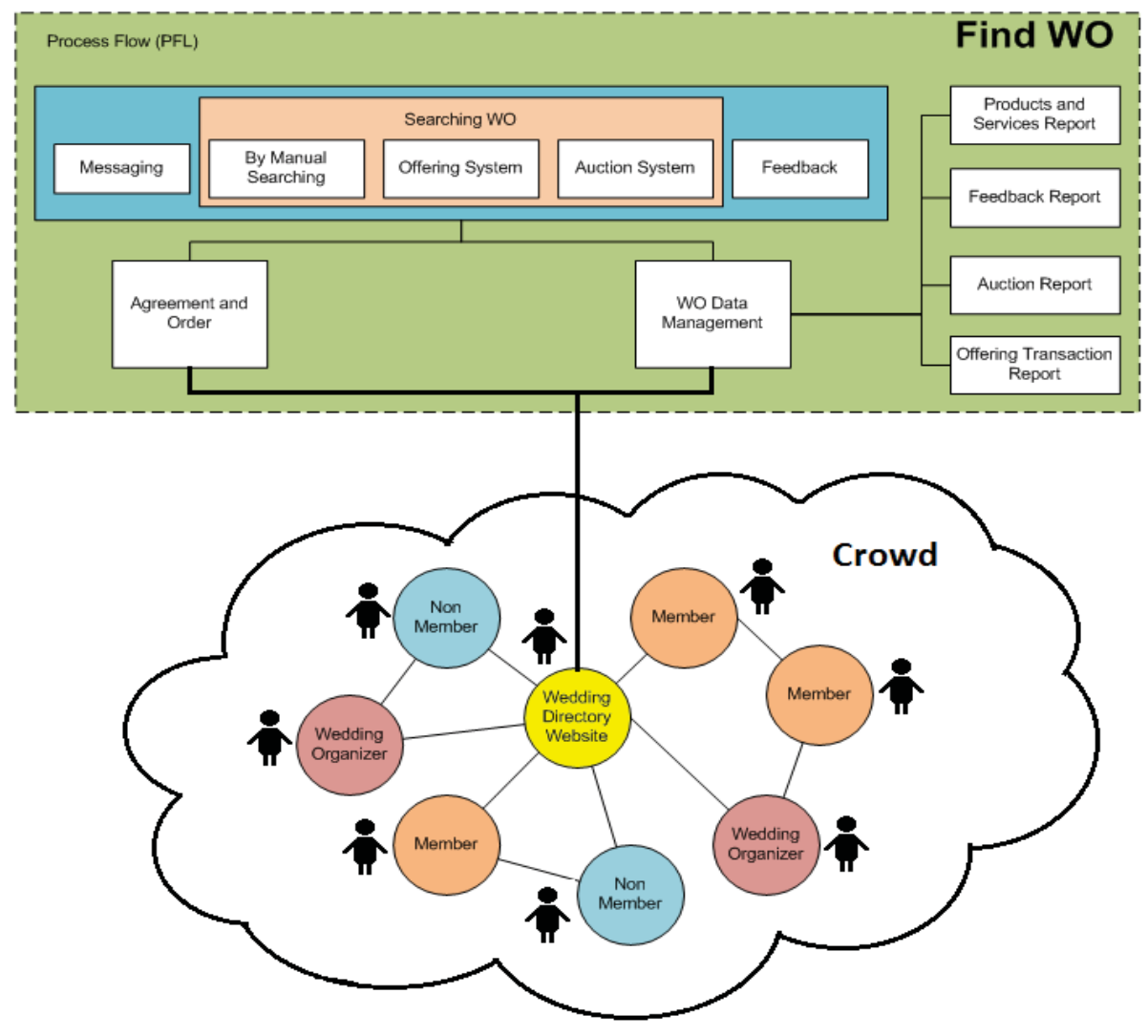

Gambar 2 Konsep Crowdsourcing dari siapsiapnikah.com 


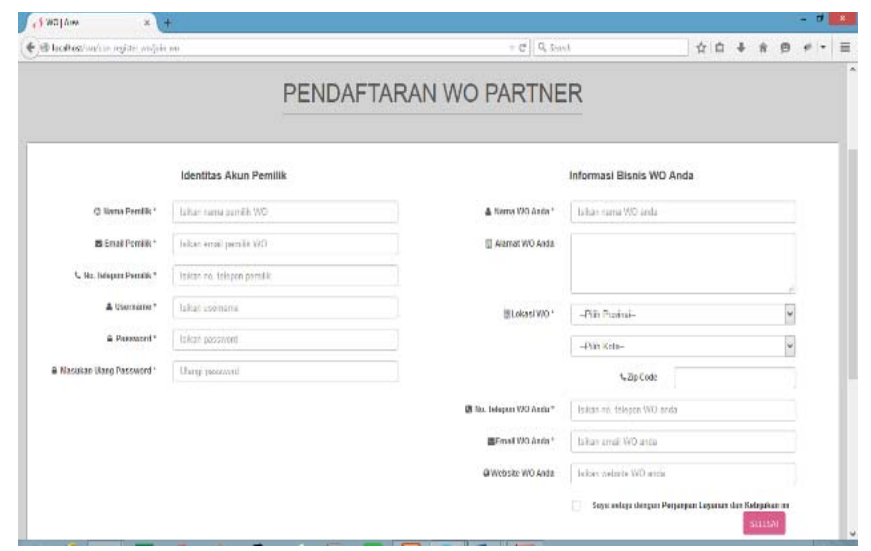

Gambar 5 Halaman Registrasi WO

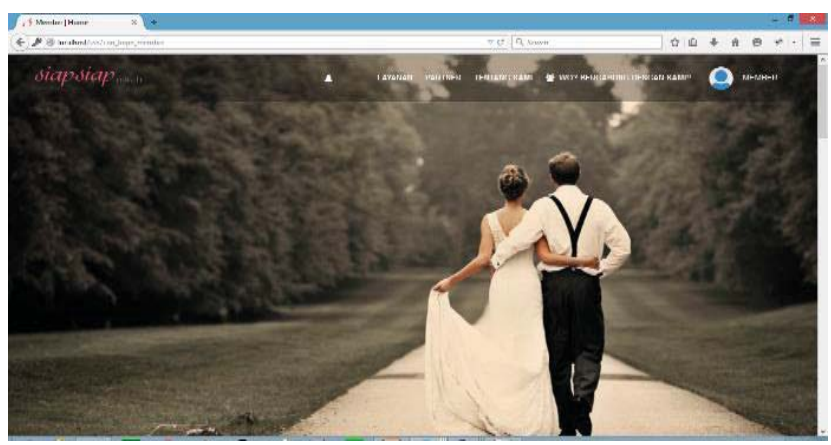

Gambar 6 Beranda Member

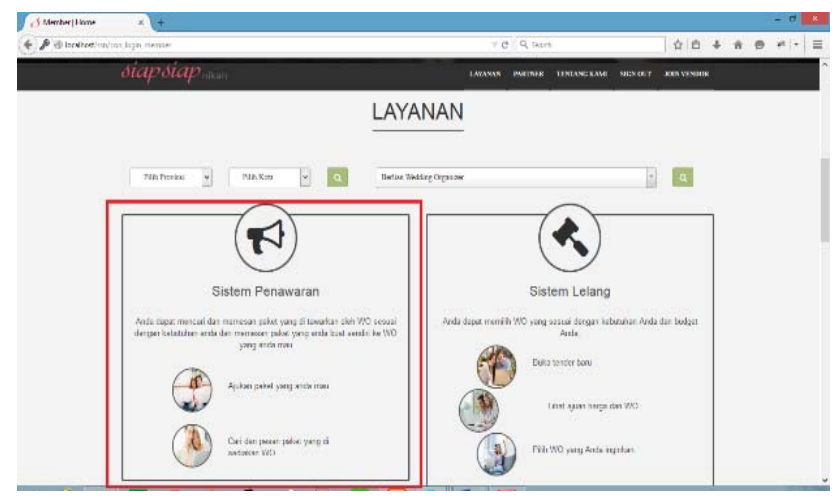

Gambar 7 Layanan siapsiapnikah.com

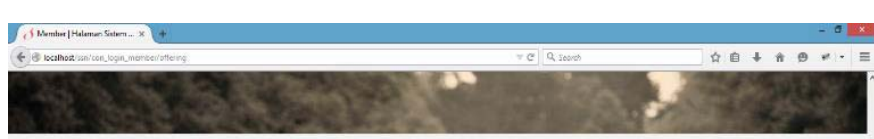

SISTEM PENAWARAN

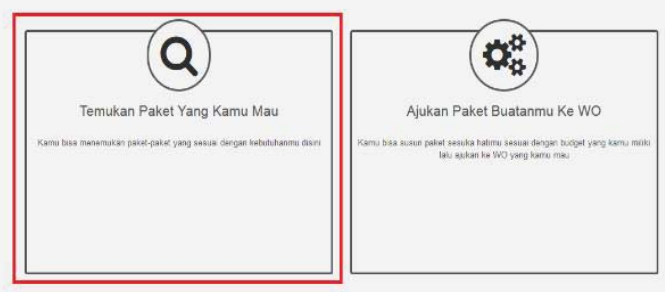

Gambar 8 Menu Temukan dan Pesan Paket

\section{Pencarian dan Pemesanan Paket}

Jika sudah masuk di halaman sistem penawaran, pelanggan dapat memilih salah satu fiturnya. Yang pertama dijelaskan adalah memilih menu menemukan dan memesan paket (Gambar 8). Gambar 9 menjelaskan tentang halaman pencarian yang digunakan untuk menemukan paket yang paling sesuai. Pelanggan harus mengisi kategori pencarian sesuai dengan kebutuhan mereka untuk menemukan paket yang sesuai. Setelah menemukan paket yang sesuai, pelanggan dapat melihat uraian paket dan dapat langsung memesannya jika memang paket tersebut sudah sesuai. Data pemesanan akan muncul pada halaman daftar pesanan paket (Gambar 10).

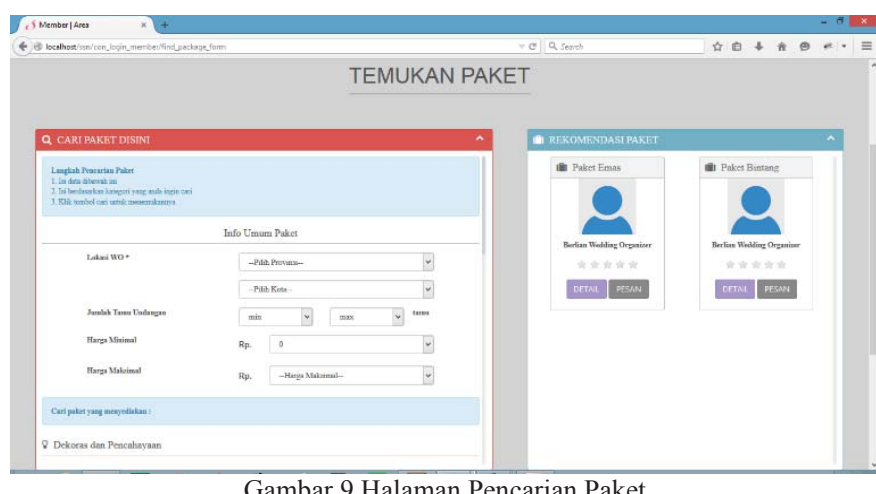

Gambar 9 Halaman Pencarian Paket

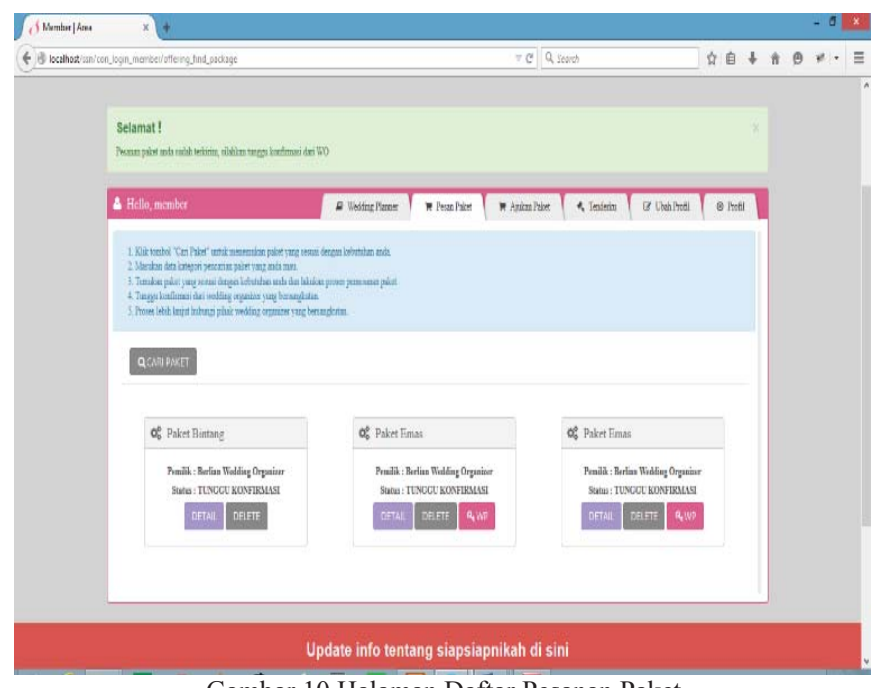

Gambar 10 Halaman Daftar Pesanan Paket

2. Pemesanan Paket Buatan Pelanggan

Selain menemukan dan memesan paket, pelanggan juga dapat mengajukan paket buatan mereka kepada WO yang ditentukan. Pelangan harus masuk ke halaman pengajuan paket (Gambar 12). Pada halaman ini pelanggan harus menekan tombol "tambahkan pesanan" untuk mengisi formulir pengajuan paket. Formulirnya dapat dilihat pada Gambar 13. Setelah itu, pelanggan mengisi formulir dan mengajukan ke WO yang dipilih. Langkah selanjutnya adalah menunggu konfirmasi dari WO. 


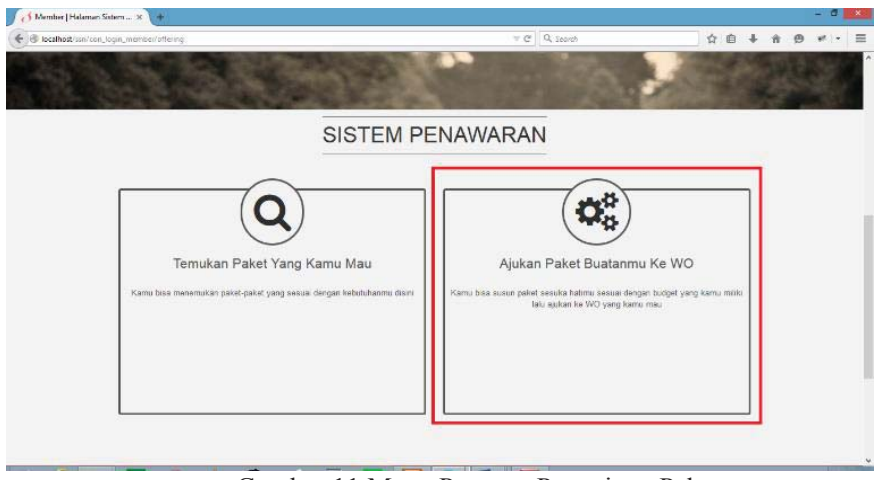

Gambar 11 Menu Pesanan Pengajuan Paket

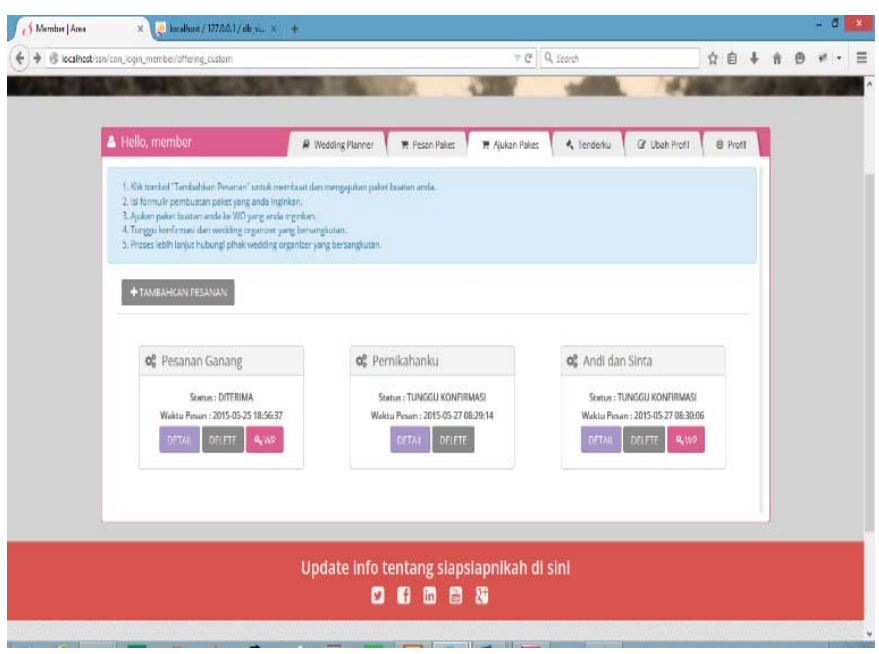

Gambar 12 Halaman Daftar Pesanan Pengajuan Paket

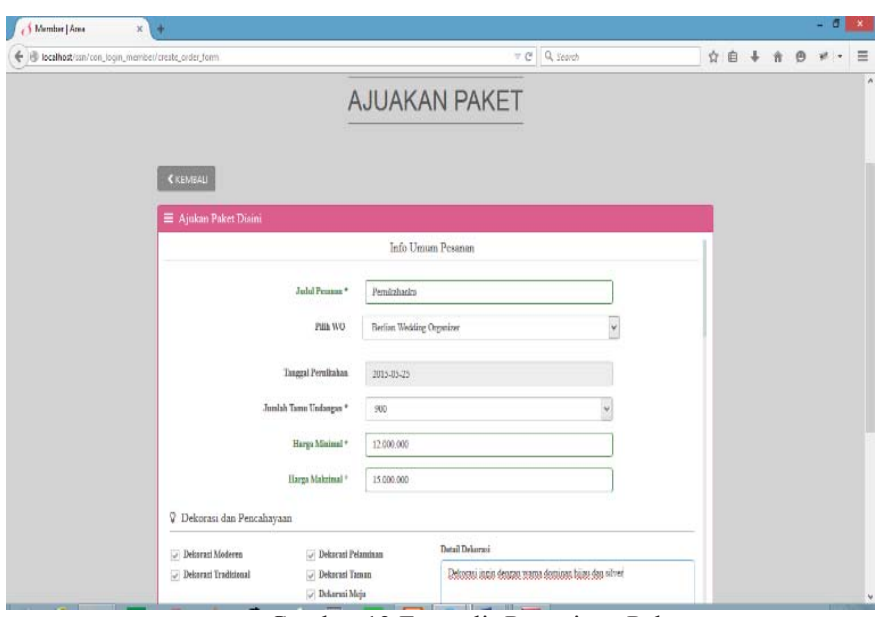

Gambar 13 Formulir Pengajuan Paket

\section{UI Wedding Planner}

Pada Gambar 14 terdapat dua macam daftar pesanan yang sesuai dengan dua fitur pada sistem penawaran.WO dapat memanajemen semua pesanan dengan cara melihat uraian pesanan, memberikan konfirmasi pesanan (diterima atau ditolak), melihat uraian pemesan, dan menghapus pesanan. Uraian pesanan dapat dilihat pada Gambar 15. Dengan fitur ini, WO dapat terbantu untuk memutuskan apakah pesanan dari pelangan diterima atau tidak.

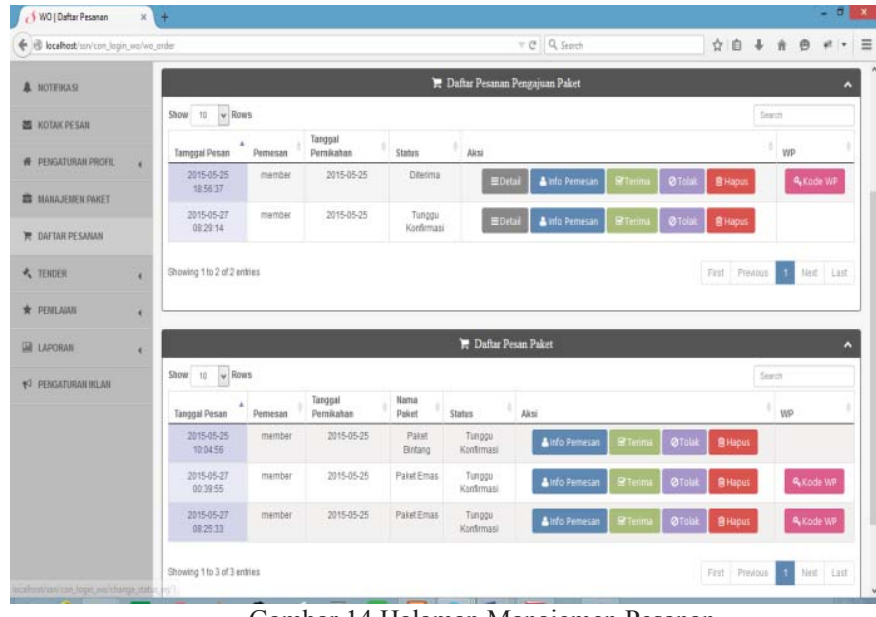

Gambar 14 Halaman Manajemen Pesanan

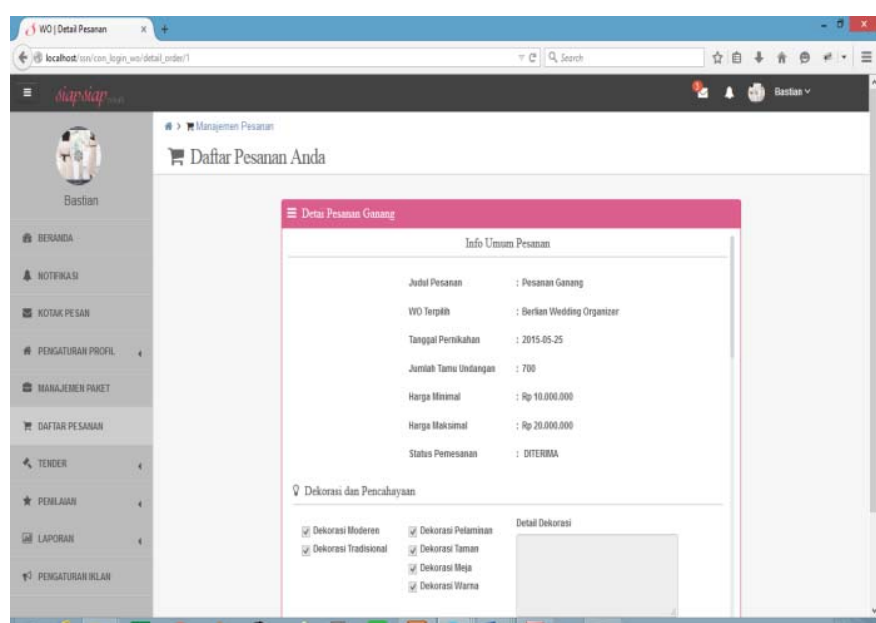

Gambar 15 Halaman Uraian Pesanan

D. Pengujian

Pada penelitian ini digunakan metode unit testing (buddy testing) dan system testing menggunakan functional technique untuk mengetahui krmampuan website ini bekerja dan apa saja kekurangan dari website ini. Buddy testing yang termasuk unit testing merupakan salah satu pendekatan testing yang melibatkan tim pengembangan software dalam proses pengujian aplikasi [7]. Selain itu, system testing merupakan level pengujian yang paling inti dari pengembangan aplikasi. Pada pengujian ini, sangat dibutuhkan skill dari pengujinya [7]. Tabel II adalah sekenario pengujiannya.

1. Unit Testing

Unti testing pada penelitian ini menggunakan dua macam web browser yaitu Mozilla Firefox dan Google Chrome. Komponen yang menjadi kategori pengujian adalah fitur dari sistem penawarana. Pada proses pengujian, setiap web browser memiliki spesifikasi masing-masing. Dengan pengujian ini yang berdasarkan pada rencana testing, menunjukan perbedaan pada tampilan fitur sistem penawaran. Penguji pada testing ini adalah partner satu tim dalam pengembangan website ini. Hasilnya dapat dilihat pada Tabel III. 
TABEL II

SEKENARIO UNIT TESTING

\begin{tabular}{|c|c|c|c|c|}
\hline Penguna & Uraian Aktivitas & Pengujian & $\begin{array}{l}\text { Tipe } \\
\text { Penguji } \\
\text { an }\end{array}$ & Kode \\
\hline \multirow[t]{10}{*}{ Member } & $\begin{array}{l}\text { Menemukan paket } \\
\text { yang sesuai }\end{array}$ & Test to pass & blackbox & O22-01 \\
\hline & Lihat uraian paket & Test to pass & blackbox & $\mathrm{O} 22-02$ \\
\hline & \multirow{2}{*}{$\begin{array}{l}\text { Membuat pesanan } \\
\text { paket baru }\end{array}$} & Test to pass & blackbox & O23-01 \\
\hline & & Test to fail & blackbox & $\mathrm{O} 23-02$ \\
\hline & $\begin{array}{l}\text { Lihat uraian pesanan } \\
\text { paket }\end{array}$ & Test to pass & blackbox & $\mathrm{O} 24-02$ \\
\hline & Hapus pesanan paket & Test to pass & blackbox & O25-01 \\
\hline & \multirow{2}{*}{$\begin{array}{l}\text { Membuat pesanan } \\
\text { pengajuan paket baru }\end{array}$} & Test to pass & blackbox & O26-01 \\
\hline & & Test to fail & blackbox & O26-01 \\
\hline & $\begin{array}{l}\text { Lihat uraian pesanan } \\
\text { pengajuan paket }\end{array}$ & Test to pass & plackbox & $\mathrm{O} 27-01$ \\
\hline & $\begin{array}{l}\text { Hapus pesanan } \\
\text { pengajuan paket }\end{array}$ & Test to pass & plackbox & O28-01 \\
\hline \multirow[t]{10}{*}{ WO } & $\begin{array}{l}\text { Lihat daftar pesanan } \\
\text { paket }\end{array}$ & Test to pass & plackbox & O29-01 \\
\hline & $\begin{array}{l}\text { Menerima pesanan } \\
\text { paket }\end{array}$ & Test to pass & blackbox & O30-01 \\
\hline & $\begin{array}{l}\text { Menolak pesanan } \\
\text { paket }\end{array}$ & Test to pass & plackbox & O31-01 \\
\hline & Hapus pesanan paket & Test to pass & blackbox & O32-01 \\
\hline & $\begin{array}{l}\text { Lihat daftar pesanan } \\
\text { pengajuan paket }\end{array}$ & Test to pass & blackbox & O33-01 \\
\hline & $\begin{array}{l}\text { Lihat uraian pesanan } \\
\text { pengajuan paket }\end{array}$ & Test to pass & plackbox & O34-01 \\
\hline & $\begin{array}{l}\text { Menerima pesanan } \\
\text { pengajuan paket }\end{array}$ & Test to pass & blackbox & O35-01 \\
\hline & $\begin{array}{l}\text { Menolak pesanan } \\
\text { pengajuan paket }\end{array}$ & Test to pass & plackbox & O36-01 \\
\hline & $\begin{array}{l}\text { Hapus pesanan } \\
\text { pengajuan paket }\end{array}$ & Test to pass & plackbox & O37-01 \\
\hline & Lihat uraian pembeli & Test to pass & plackbox & O38-01 \\
\hline
\end{tabular}

TABEL III

HASIL UNIT TESTING

\begin{tabular}{|l|l|l|l|l|}
\hline Pengguna & Jumlah Tugas & Web Browser & Berhasil & Gagal \\
\hline Pelanggan & 8 & $\begin{array}{l}\text { Mozzila } \\
\text { Firefox }\end{array}$ & 8 & 0 \\
\cline { 3 - 5 } & & $\begin{array}{l}\text { Google } \\
\text { Chrome }\end{array}$ & 8 & 0 \\
\hline $\begin{array}{l}\text { Wedding } \\
\text { organizer }\end{array}$ & 10 & $\begin{array}{l}\text { Mozzila } \\
\text { Firefox }\end{array}$ & 10 & 0 \\
\cline { 3 - 5 } & & $\begin{array}{l}\text { Google } \\
\text { Chrome }\end{array}$ & 10 & 0 \\
\hline
\end{tabular}

\section{2. $\quad$ System Testing}

Tujuan dari system testing ini untuk mengetahui seberapa baik aplikasi website dan apakah tujuan dari pembuatan aplikasi ini sudah terpenuhi. Yang melakukan pengujian adalah pihak pengguna. Dari sisi member ada tujuh orang penguji dan dari sisi WO ada dua WO yang telah melakukan pengujian. Materi pengujian dan kuesionernya diambil dari skala service quality (SERVQUAL). SERVQUAL bertujuan untuk mengetahui kualitas layanan dari berbagai macam layanan industry yang dapat juga digunakan untuk mengukur kualitas layanan dalam konteks $e$-service [8]. Tabel IV menunjukkan hasil pengujian usability, sedangkan Tabel V menunjukan hasil kuesioner pengujian usability dengan acuan pertanyaan dari metode SERVQUAL.
TABEL IV

HASIL SYSTEM TESTING

\begin{tabular}{|c|c|c|}
\hline No & Tugas & $\begin{array}{c}\text { Persentase } \\
\text { berhasil }\end{array}$ \\
\hline \multicolumn{3}{|c|}{ PELANGGAN } \\
\hline 1. & Menemukan paket dengan fitur pencrian & $100 \%$ \\
\hline 2. & Lihat uraian paket & $100 \%$ \\
\hline 3. & Pesan paket & $100 \%$ \\
\hline 4. & Lihat uraian pesanan paket & $100 \%$ \\
\hline 5. & Hapus pesanan paket & $100 \%$ \\
\hline 6. & Ajukan pesanan custom paket & $85,71 \%$ \\
\hline 7. & Lihat uraian pesanan custo paket & $100 \%$ \\
\hline 8. & Hapus pesanan custom paket & $100 \%$ \\
\hline \multicolumn{3}{|c|}{ WEDDING ORGANIZER } \\
\hline 9 & Lihat daftar pesanan paket & $100 \%$ \\
\hline 10. & Lihat daftar pesanan custom paket & $100 \%$ \\
\hline 11. & Terima pesanan paket & $100 \%$ \\
\hline 12. & Tolak pesanan paket & $100 \%$ \\
\hline 13. & Terima pesanan custom paket & $100 \%$ \\
\hline 14. & Tolak pesanan custom paket & $100 \%$ \\
\hline 15. & Lihat uraian pesanan & $100 \%$ \\
\hline 16. & Lihat uraian pelanggan & $100 \%$ \\
\hline 17. & Hapus pesanan & $100 \%$ \\
\hline
\end{tabular}


TABEL $V$

HASIL PENGUKURAN SERVICE QUALITY SIAPSIAPNIKAH.COM DENGAN SKALA SERVQUAL

\begin{tabular}{|c|c|c|c|c|c|}
\hline No & Skala & Pertanyaan & $\begin{array}{l}\text { Sangat } \\
\text { Setuju }\end{array}$ & Setuju & $\begin{array}{l}\text { Tidak } \\
\text { Setuju }\end{array}$ \\
\hline 1. & \multirow[b]{2}{*}{ Web Design } & Apakah navigasi, menu dan fungsi pada website ini mudah digunakan dan mudah dimengerti? & $33 \%$ & $67 \%$ & $0 \%$ \\
\hline 2. & & $\begin{array}{l}\text { Apakah desain pada website ini seperti penempatan ikon, gambar dan warna membuat Anda nyaman } \\
\text { menggunakan website ini? }\end{array}$ & $44 \%$ & $56 \%$ & $0 \%$ \\
\hline 3. & \multirow{4}{*}{ Reliability } & $\begin{array}{l}\text { Apakah mekanisme pencarian dan pengajuan produk/jasa pada website ini meyakinkan Anda bahwa } \\
\text { informasi yang diberikan bersifat akurat? }\end{array}$ & $43 \%$ & $57 \%$ & $0 \%$ \\
\hline 4. & & $\begin{array}{l}\text { Apakah website ini mengakomodasi pengguna untuk mencari paket dan memesan paket yang sesuai } \\
\text { dengan keinginan pengguna? }\end{array}$ & $86 \%$ & $14 \%$ & $0 \%$ \\
\hline 5 . & & $\begin{array}{l}\text { Apakah website ini mengakomodasi pengguna untuk membuat paket dan menerima/menolak } \\
\text { permintaan pesanan. }\end{array}$ & $50 \%$ & $50 \%$ & $0 \%$ \\
\hline 6. & & Apakah website ini mengakomadasi pengguna untuk meneri pesanan diluar paket? & $50 \%$ & $50 \%$ & $0 \%$ \\
\hline 7. & \multirow[b]{2}{*}{ Responsiveness } & Apakah website ini menyediakan mekanisame untuk mendukung aktivitas pengguna? & $22 \%$ & $78 \%$ & $0 \%$ \\
\hline 8. & & $\begin{array}{l}\text { Apakah website ini menyediakan mekanisme untuk mendukung komunikasi antarapengguna dengan } \\
\text { pemilik website? }\end{array}$ & $56 \%$ & $33 \%$ & $11 \%$ \\
\hline 9. & \multirow[t]{2}{*}{ Security } & $\begin{array}{l}\text { Apakah website ini menyediakan mekanisme untuk meyakinkan pengguna bahwa data dapat } \\
\text { terimpan dengan aman? }\end{array}$ & $67 \%$ & $22 \%$ & $11 \%$ \\
\hline 10. & & Apakah website ini menyediakan mekanisme untuk melindungi aktivitas dan data pengguna? & $67 \%$ & $33 \%$ & $0 \%$ \\
\hline 11. & \multirow{5}{*}{ Fulfillment } & Apakah website ini sudah mencapai tujuan utamanya? & $44 \%$ & $56 \%$ & $0 \%$ \\
\hline 12. & & Apakah website ini dapat membantu untuk mencari paket yang sesuai? & $57 \%$ & $43 \%$ & $0 \%$ \\
\hline 13. & & Apakah website ini dapat membantu untuk memesan paket yang sesuai? & $43 \%$ & $57 \%$ & $0 \%$ \\
\hline 14. & & Apakah website ini membantu untuk mengiklankan dan mempromosikan produk dan layanan WO? & $100 \%$ & $0 \%$ & $0 \%$ \\
\hline 15. & & Apakah website ini membantu untuk mendapatkan pelanggan lebih mudah? & $50 \%$ & $50 \%$ & $0 \%$ \\
\hline 16. & Personalization & Apakah website ini memberikan nilai tambah pada pelanggan? & $57 \%$ & $43 \%$ & $0 \%$ \\
\hline 17. & \multirow{4}{*}{ Information } & Apakah website ini menyediakan informasi produk/jasa terbaru? & $43 \%$ & $57 \%$ & $0 \%$ \\
\hline 18. & & Apakah website ini menyediakan informasi yang mudah dimengerti? & $43 \%$ & $57 \%$ & $0 \%$ \\
\hline 19. & & $\begin{array}{l}\text { Apakah website ini menyediakan fasilitas untuk memperbaharui informasi produk dan layanan dari } \\
\text { WO }\end{array}$ & $50 \%$ & $50 \%$ & $0 \%$ \\
\hline 20. & & Apakah website ini menyediakan informasi tentang kompetitor? & $100 \%$ & $0 \%$ & $0 \%$ \\
\hline 21. & \multirow{2}{*}{ Empathy } & Apakah website ini menyediakan sistem untuk membuat komunikasi yang bagus antar pengguna? & $22 \%$ & $67 \%$ & $11 \%$ \\
\hline 22. & & Apakah website ini memiliki informasi mengenai kontak yang dapat dihubungi? & $78 \%$ & $22 \%$ & $0 \%$ \\
\hline
\end{tabular}

\section{KESIMPULAN DAN SARAN}

Berdasarkan hasil penelitian dan pengujian, crowdsourcing website dengan sistem penawaran untuk bisnis wedding organizer yang disebut siapsiapnikah.com adalah website yang berpotensi tinggi untuk diterapkan di Indonesia. Website ini dapat memenuhi kebutuhan penggunanya. Calon pengantin dapat mencari WO dan paket yang sesuai dengan biaya dan kualitas yang diinginkan pada satu website dan WO dapat memasarkan produknya pada satu website di internet. Website siapsiapnikah.com dapat dioperasikan baik pada dua web browser, yaitu Mozilla Firefox dan Google Chrome berdasarkan hasil penelitian ini. Untuk pengembangannya, sebaiknya aplikasi ini dicoba untuk di implementasikan pada web browser lainnya. Hal tersebut dapat dilihat pada hasil pengukuran service quality pada website ini. Aplikasi website ini juga perlu pembanahan pada segi desain website dan keamanan website. Fitur-fitur untuk melengkapi kegunaan website juga sebaiknya ditambah.

\section{DAFTAR PUSTAKA}

[1] Arum, R. E. (n.d). Lingkungan Bisnis "Wedding Organizer.

[2] Andriansyah .M., Oswari .T.,\& Prijanto .B. (n.d). Konsep Sumber Daya Kerumunan dalam Abad Partisipasi Komunitas Internet. Crowdsourcing.
[3] http://id.wikipedia.org/wiki/Penawaran dan permintaa n diakses Oktober 2014.

[4] Vliet H.V. (2008). Software Engineering Principles and Practice - 3rd ed. England: John Willey \& Sons Ltd.

[5] http://nurseammar.blogspot.kr/2012/03/makalah-modelkonseptual-model.html Perry \& potter. 1999. Fundamental keperawatan. Jakarta: EGC diakses November 2014

[6] Rahmawan, B., Adam Y.P., \& Wiyogo, M. Membangun portal web crowdsourcing health treatment dengan menggunakan metode iterative incremental dan metode pencarian vector space model. IT Telkom, Bandung, Indonesia, 2013.

[7] Khan, M.E., "Different Software Testing Levels for Detecting Errors", International Journal of Software Engineering (IJSE), Volume 2, Issue 4, 2011,pp. 70-80.

[8] Li ,Hongxiu., dan Soumi,Reima., "A Proposed Scale for Measuring E-service Quality". Information Sistem Science Institute, Turku School of Economics, Finland, 2009. 